УДК 61:007

\title{
АВТОМАТИЗОВАНА КЛІНІЧНА БАЗА МОНІТОРИНГУ ХВОРИХ НА МУКОПОЛІСАХАРИДОЗ
}

\author{
В. З. Стецюк', Н. Г. Горовенко ${ }^{2}$ А. Й. Савицький ${ }^{1}$, Н. А. Пічкур ${ }^{3}$, К. К. Китаєв \\ Конструкторське бюро інформаційних систем Національного технічного університету \\ України «Київський політехнічний інститут» 1 \\ Національна медична академія післядипломної освіти імені П. Л. Шупика² \\ Національна дитяча спеціалізована лікарня «ОХМАТДИТ»
}

\begin{abstract}
Представлено складнощі обліку даних про пацієнта, ведення медичної документації стосовно хворих на мукополісахаридоз і спостереження за ними протягом життя. Пропонуеться вирішення зазначених проблем за допомогою впровадження автоматизованої клінічної бази моніторингу хворих, що призначена для обліку та збереження інформації про хворих на мукополісахаридоз шести типів. Користувачу надається можливість створювати, редагувати, зберігати записи про пацієнтів. Також додаток має такі функції як: пошук даних про пацієнта з використанням різноманітних фільтрів, відстеження майбутніх візитів паціентів на поточний тиждень, підрахунок сумарної потреби в лікарських засобах тощо.
\end{abstract}

Ключові слова: мукополісахаридоз, автоматизована клінічна база моніторингу хворих на мукополісахаридоз.

\section{АВТОМАТИЗИРОВАННАЯ КЛИНИЧЕСКАЯ БАЗА МОНИТОРИНГА БОЛЬНЫХ МУКОПОЛИСАХАРИДОЗОМ}

\footnotetext{
В. З. Стецюк', Н. Г. Горовенкоㄹ, А. Й. Савицкий', Н. А. Пичкур ${ }^{3}$, К. К. Китаев'

Конструкторское бюро информационных систем Национального технического университета Украины "Киевский политехнический институт»"

Национальная медицинская академия последипломного образования имени П. Л. Шупика² Национальная детская специализированная больница "ОХМАТДЕТ»з

\begin{abstract}
Представлено сложности учета данных о пациенте, ведение медицинской документации про больных мукополисахаридозом и наблюдение за ними на протяжении жизни. Предлагается решение указанных проблем с помощью внедрения автоматизированной клинической базы мониторинга больных мукополисахаридозом, которая предназначена для учета и хранения информации о больных мукополисахаридозом шести типов. Пользователю предоставляется возможность создавать, редактировать, сохранять записи о пациентах. Также у приложения есть такие функции как: поиск данных пациента с использованием разнообразных фильтров, отслеживание будущих визитов пациента на текущей неделе, подсчет суммарной потребности в лекарственных средствах и другие.
\end{abstract}

Ключевые слова: мукополисахаридоз, автоматизированная клиническая база мониторинга больных мукополисахаридозом.

\section{AUTOMATED CLINICAL DATABASE FOR MONITORING OF PATIENTS MUCOPOLYSACHARIDOSISWITH}

\author{
V. Z. Stetsiuk', N. H. Horovenko², A. Y. Savytskyi', N. A. Pichkur ${ }^{3}$, K. K. Kytaiev' \\ Design Office of Information Systems of National Technical University of Ukraine «Kyiv \\ Polytechnic Institute»? \\ National Medical Academy of Postgraduate Education ${ }^{2}$ by P. L. Shupyk \\ National Children's Specialized Hospital «OHMATDYT»3
}

\begin{abstract}
This article describes the complexity of managing medical records of patients with MPS and monitoring them throughout their live. A general solution of these problems is produced by implementing an automated clinical database for monitoring the patients with mucopolysacharidosis. This application is designed to record and store information about patients with six types of MPS. The user can create, edit, store patient records, which include such data as the patients passport information,
\end{abstract}

С В. З. Стецюк, Н. Г. Горовенко, А. Й. Савињький, Н. А. Пічкур, К. К. Китаєв 
visits, test results, method of treatment, objective status. Also, the application has such functions such as : patient data search using a variety of filters, tracking patients visits on current week, estimation of the total requirement of drugs and the cost of these drugs.

Key words: mucopolysacharidosis automated clinical database of monitoring of patients with mucopolysacharidosis.

Вступ. Мукополісахаридози - це група спадкових тяжких інвалідизуючих захворювань, зумовлених деградацією та подальшим накопиченням глікозаміногліканів всередині клітин. Усього існує 7 різних типів мукополісахаридозу (МПС) різного ступеня тяжкості. Впродовж останніх десятиріч сучасна медична наука розробила ефективні методи лікування цих хворих. Лікування проводиться за життєвими показаннями протягом всього життя. Тому лікарю необхідно здійснювати постійний моніторинг стану здоров'я пацієнтів з мукополісахаридозом. Крім того, важливим аспектом проведення запропонованого лікування є розрахунок адекватної дози лікарського засобу, враховуючи полісиндромну картину захворювання, фізичний стан хворих, глибину ушкодження центральної нервової системи. Також є необхідність в написані звітів по лікарських засобах проти мукополісахаридозу. Препарати, які використовують для лікування цього захворювання, належать до групи орфанних (рідкісних), і тому високовартісних. У європейських країнах, як і в Україні, ці ліки закуповуються за кошти державного бюджету і запропонована програма допомагає здійснити чіткий розрахунок потреби у лікарському засобі (ЛЗ).

Мета роботи - розробка та впровадження автоматизованої клінічної бази моніторингу хворих із мукополісахаридозами.

Матеріал і методи дослідження. Об'єктом даного дослідження стали інформаційні потоки метаболічного центру захворювань на мукополісахаридоз. Предмет дослідження: форми медичної документації (картка пацієнта, бланк аналізів тощо), порядок подання медичних документів, форми звітування щодо застосування ЛЗ проти мукополісахаридозу, довідникова інформація стосовно хвороби. Методи дослідження: аналітичний, описовий, статистичні методи оброблення інформації. Для розроблення програмного

\section{Лiтература}

1. Visual C\# 2008 : базовый курс / К. Уотсон, К. Нейгел, Д. Рид [и др.] ; пер. с англ. Я. П. Волклвой, Д. Я. Иваненко, Ю. И. Корниенко [и др.] ; зав. ред. С. Н. Тригуб.-М. ООО «И. Д. Вильямс», 2009. - 1216 с. - Парал. тит. англ. - ISBN 978-5-8459-1532-0 продукту застосовували мову програмування С\# та базу даних Microsoft SQL Server 2008R2 Express.

Результати та ïx обговорення. Розроблений та впроваджений програмний продукт дозволяє вирішувати такі завдання:

1. Зберігання, введення, редагування даних про пацієнта в базі даних.

2. Зберігання, введення, редагування даних про проведені лабораторні та інструментальні дослідження (зокрема, електрокардіографія, ехокардіографія, електронейроміографія, рентгенографія, пульмосонографія, магнітно-резононасна томографія, ультразвукове дослідження органів черевної порожнини) у базі даних.

3. Зберігання, введення, редагування відомостей у базі даних про призначення та прийом ЛЗ.

4. Проведення пошуку пацієнтів за певними фільтрами.

5. Формування звіту витрат на Л3, необхідні пацієнтам, отримання версії для друкування.

6. Повідомлення користувачу додатку про найближчі за часом візити на тиждень, у зручному для нього форматі.

7. Моніторинг усіх даних пацієнтів, хворих на мукополісахаридоз.

Висновок. Програмний продукт містить всі форми вводу необхідної інформації про пацієнта, забезпечує іiі збереження та читання у відповідному вигляді; спрощує навігацію по записах пацієнтів завдяки інтуїтивно зрозумілому інтерфейсу. На основі принципів доказової медицини програма дозволяє створювати базу даних, здійснювати ефективний моніторинг стану здоров'я, проводити розрахунок потреби лікарського засобу, спираючись на всебічне вивчення особливостей перебігу захворювання, впровадити індивідуальний підхід до кожного пацієнта 3 МПС.

2. Ицик Б. Microsoft Sql Server 2008. Основы T-SQL / Б. Ицик ; пер. с англ. Т. Коротяевой ; глав. ред. Е. Кондукова ; зав. ред. Г. Добин. - СПб. : БХВ-Петербург, 2009. -432 с. : ил. - ISBN 978-5-9775-0220-7. 